\title{
Case-Based Reasoning dalam Menentukan Faktor yang Mempengaruhi Kenakalan Remaja
}

\author{
Rosmala Dwi \\ Mahasiswa Program Pascasarjana FMIPA, Universitas Lampung \\ Dosen Program Studi Teknik Informatika, Universitas Nahdlatul Ulama Lampung \\ Lampung, Indonesia \\ rosmaladarma@gmail.com
}

\begin{abstract}
ABSTRAK - Kenakalan remaja merupakan permasalahan yang terjadi sejak lama, dimana penyebabnya belum dapat diketahui. Perilaku yang menyalahi aturan sosial dilingkungan masyarakat ini dapat disebabkan oleh banyak hal. Namun pola hidup masyarakat sekitar dan sikap mental yang dimiliki sangat mempengaruhi perilaku. Perilaku menyimpang remaja merupakan objek penelitian yang dilakukan saat ini. Dengan memanfaatkan permasalahan yang pernah terjadi sehubungan dengan perilaku remaja yang menyimpang, maka dalam penelitian ini akan digunakan tahapan yang ada didalam teknik Case-Based Reasoning (CBR) yaitu dengan mencari kesamaan yang ada pada kasus yang pernah ada sebelumnya, kemudian memanfaatkan kembali pengetahuan yang ada untuk menyelesaikan masalah yang sedang dihadapi. Setelah diperoleh solusi yang pernah digunakan untuk menyelesaikan permasalahan kenakalan remaja sebelumnya maka akan dilakukan peninjauan pada solusi ini untuk kemudian diguakan pada permasalahan yang baru. Selanjutnya juka tidak ada persamaan dengan kasus sebelumnya, maka kasus baru ini akan ditambahkan kedalam database guna mengembangkan database yang ada agar dapat digunakan untuk mennyelesaikan kasus berikutnya. Satu hal penting lainnya dalam menggunakan teknik ini adalah dengan memperhatikan tingkat kedekatan permasalahan yang sedang dihadapi dengan permasalahan yang tersimpan didalam database. Dalam penelitian ini algoritma yang digunakan untuk mencari tingkat kemiripan permasalahan baru dengan permasalahan yang ada yaitu Algoritma Nearst Neighboar.
\end{abstract}

Kata Kunci: Kenakalan Remaja, Case Based-Reasoning, CBR, Similaritas, Nearst Neighboar

\section{PENDAHULUAN}

Perilaku menyimpang terhadap norma yang berlaku didalam masyarakat banyak dilakukan oleh remaja. Hal ini merupakan sebuah kebanggan tersendiri bagi remaja dan kelompoknya, seperti yang sering diterjadi dikota besar seperti Makassar, dan Jakarta.

Banyak faktor yang dapat menyebabkan perilaku menyimpan dari seorang remaja, diantaranya kondisi lingkungan sekitar dan keluarga

Memanfaatkan permasalahan perilaku menyimpang remaja yang tersimpan dialam database untuk kemudian membandingkan dan mencari tingkat kemiripan yang dekat dengan permasalahan remaja yang sedang dihadapi merupakan tahapan yang ada didalam Case-Based Reasoning dalam menyelesaikan permasalahan. Kasus yang telah tersimpan didalam database yang bersumber dari pengalaman seseorang atau pengalaman seorang pakar yang terkait dengan bidangnya merupakan sumber pengetahuan utama bagi metode CBR untuk melakukan pendekatan terhadap kasus baru yang dihadapi. Metode Case-Based Reasoning banyak diterapkan diberbagai bidang, diantaranya psikologi yang digunakan untuk mendiagnosa permasalahan yang dihadapi kliennya. Teknik Case-Based Reasoning dan algoritma Nearst Neighboard digunakan untuk menganalisa penyebab terjadinya perilaku menyimpang pada seorang remaja berdasarkan tingkat kesamaan permasalahan didalam database dengan yang sedang dihadapi

Database pada sistem Case-Based Reasoning dibangun dengan menggunakan fitur-fitur yang berasal dari idikasi permasalahan remaja yang berkonsultasi. Indikator 1 (ya) atau pun 0 (tidak) merupakan nilai masukan yang akan digunakan system untuk menyatakan ada atau tidaknya masukan. Dimana nilai kedekatan kasus yang sedang dialami oleh remaja yang bersangkutan dengan kasus yang ada didalam database kasus yang ada dengan menggunakan algoritma Nearst Neighboar.

\section{DASAR TEORI}

A. Kenakalan Remaja dan Faktor yang Mempengaruhi

Remaja dalam pertumbuhannya mengalami perubahan secara fisik ataupun mental seorang anak dari masa anak-anak menjadi seorang dewasa sehingga dimasa pertumbuhannya tidak menutup kemungkinan menemui permasalahan [1].

Dalam masa perkembangan kepribadiannya, seorang remaja mempunyai arti yang khusus. Didalam setiap masa perkembangan seorang manusia ada kriteria-kriteria tertentu yang terpenuhi baik masa anak-anak ataupun dewasa. Karena masih banyak kriteria untuk dikatakan dewasa yang belum dipenuhi maka remaja lebih tepatnya dikatakan anak-anak daripada dewasa. Baru pada akhir abad ke 18 maka masa remaja dipandang sebagai masa perkembangan tertentu lepas dari masa anak-anak [2]. Seorang remaja akan mengalai perubahan menuju ke masa dewasa yang dimulai dari usia 12 tahun (masa remaja awal). Kemudian diusia 15 tahun seorang remaja akan memasuki usia remaja pertengahan. Diusia 18 tahun 
seorang remaja akan memasuki masa akhir seorang remaja hingga akhirnya menjadi seorang yang dewasa yaitu diusia 21 tahun [3].

Didalam masa perkembangan sesuai dengan tahap perkem bangan individunya seorang remaja mempunyai tugas/kewajiban yang harus dilaluinya sesuai dengan tahap pertumbuhannya [4]. Dimana tugas yang harus dipenuhi pada tahap perkembangan masa remaja adalah:

1) Mau menerima keadaan fisik apa adanya.

2) Memahami peran seks usia dewasa.

3) Hubungan dengan lawan jenis dan antar anggota/kelompok dapat dibangun dengan harmonis.

4) Mampu mengembangkan kreatifitas serta ketrampilan intelektual dapat mandiri baik secara emosional ataupun financial sehingga dapat memahami nilai orang dewasa.

5) Mampu mengembangkan konsep dan pemahamanan tentang tanggung jawab keluarga.

Ketidakmampuan remaja dalam mengembangkan ketrampilan didalam masyarakat untuk mendapat perhatian dan status positif sehingga mengakibatkan remaja melakukan tindakan dengan perbuatan menyimpang dari aturan yang berlaku dimasyarakat sekitarnya. Menurut Cavan dalam Willis [5] dalam bukunya yang berjudul Juvenile Delinquent dijelaskan bahwa ganguan yang terjadi pada anak remaja sering disebut dengan kenakalan remaja, karena dari anak remaja ini ada kewajiban yang harus dipenuhi yang merupakan harapan dari lingkungan sosial dimana saja mereka berada namun tidak terpenuhi.

Menurut Adler dalam buku Kartono [6] dijelaskan bentuk-bentuk kenakalan remaja, seperti:

1) Perilaku melanggar keamanan lalu lintas, seperti balapan motor.

2) Suka membuat keonaran yang mengakibatkan terganggunya ketentraman lingkungan sekitar karena adanya dorongan energi negatif yang tidak terkontrol, seperti perkelahian antar gang, melakukan tindakan criminal, pesta pora yang mengakibatkan munculnya seks bebas dan penggunaan minuman keras dan penggunaan narkoba, permainan judi, membolos dari sekolah.

3) Tidak adanya kemampuan menerima kekurangan fisik sehingga memunculkan perilaku menyimpang untuk mendapatkan pengakuan dari lingkungan sekitar.

Adanya proses pengkondisian lingkungan yang buruk terhadap perkembangan mental remaja yang masih labil disebut dengan kenakalan remaja [5]. Permasalahan remaja didalam keluarga yang tidak dapat diselesaikannya merupakan salah satu faktor penyebab munculnya kenalan remaja [6]. Kenakalan remaja dapat dipengaruhi dengan berbagai faktor ${ }^{[7]}$ yaitu:

1) Identitas; Masa pubertas atau remaja merupakan tahap dimana identitas versus krisis identitas yang harus dicarikan solusinya. Tahapan perkembangan yang telah dilalui sejak masa balita, masa kanak hingga masa remaja yang membatasi peran sosial yang dapat diterima atau tidak dalam memenuhi tuntutan yang dibebankan. Ada sebagian remaja berperilaku yang melanggar ketentuan dalam membentuk identitas diri walaupun dengan cara tidak benar.

2) Kendali Diri; Kegagalan dalam melakukan pengembangan kendali diri dapat dilihat dari tingkah laku.

3) Usia; Perilaku anti sosial diusia dini mempunyai pengaruh buruk terhadap pembentukan karakter diusia remaja, walaupun tidak semuanya.

4) Jenis Kelamin; Sebagian besar sikap anti sosial banyak terjadi remaja laki-laki daripada perempuan.

5) Harapan terhadap pendidikan dan nilai-nilai disekolah; Rendahnya keinginan sekolah yang disebabkan kurangnya motivasi dan harapan dari pelaku kenakalan remaja terhadap manfaat pendidikan disekolah.

6) Proses Keluarga; Faktor keluarga sangat berpengaruh terhadap timbulnya kenakalan remaja. Hal ini diakibatkan karena kurangnya dukungan keluarga, seperti kurangnya perhatian orang tua terhadap aktivitas anak, kurangnya penerapan disiplin yang efektif, kurangnya kasih sayang orang tua dapat menjadi pemicu timbulnya kenakalan remaja.

7) Pengaruh Teman Sebaya; Memiliki teman sebaya yang melakukan kenakalan meningkatkan resiko remaja untuk nakal.

8) Kelas Sosial Ekonomi; Kurangnya kesempatan remaja dari kelas sosial rendah untuk mengembangkan ketrampilan mengakibatkan mereka untuk mendapatkan perhatian dan status sehingga mereka melakukan tindakan anti sosial. Hal ini mengakibatkan kecenderungan pelaku kenakalan lebih banyak berasal dari kelas sosial ekonomi rendah dengan perbandingan jumlah remaja nakal diantara daerah perkampungan miskin yang rawan dengan daerah yang banyak memiliki privilege.

9) Kualitas Lingkungan Sekitar Tempat Tinggal; Dimana komunitas juga berperan dalam memunculkan kenakalan remaja. Lingkungan masyarakat dengan tingakt kriminalitas tinggi memungkinkan remaja mengamati berbagai model yang melakukan aktivitas kriminal mereka.

\section{B. Case Based-Reasoning (CBR)}

Basis/ Kumpulan pengetahuan yang digunakan untuk menyelesaikan masalah sering disebut dengan basis pengetahuan. Untuk membentuk basis pengetahuan, ada 2 pendekatan yang dapat digunakan yaitu [9]:

1) Pendekatan berbasis aturan (Rule-Base Reasoning); Untuk merepresentasikan pendekatan ini yaitu dengan menggunakan aturan berbentuk JIKAMAKA. Model ini digunakan untuk menyelesaikan masalah secara berurutan.

2) Pembelajaran berbasis kasus (Case-Based Reasoning); Merupakan sebuah model yang menggunakan 
pengalaman lama untuk dapat dimengerti dan menyelesaikan masalah baru.

Case-Based Reasoning adalah sebuah mesin pembelajaran dengan memperhatikan kemiripan yang ada pada kasus baru dengan kasus yang ada sebelumnya untuk digunakan dalam menyelesaikan permasalahan yang sedang dihadapi [8].

Mencari tingkat kemiripan/ similaritas yang tinggi terhadap permasalahan yang dihadapi dengan permasalahan yang tersimpan di database dengan melalui beberapan proses merupakan teknik yang digunakan Case-Based Reasoning (CBR) untuk dapat menyelesaikan permasalahan yang dihadapi. Ada 4 proses yang dilakukan secara berurut didalam teknik Case-Based Reasoning (CBR) yaitu [10]:
1) Retrieve; Disini akan dilakukan proses mengidentifikasi permasalahan yang baru.

2) Reuse; Dengan meggunakan identifikasi masalah baru, maka sistem akan melakukan pencarian masalah terdahulu didalam database yang tersimpan untuk digunakan kembali sebagai solusi penyelesaian masalah baru jika mempunyai identifikasi masalah yang sama.

3) Revise; Informasi dari permasalahan lama akan dievaluasi ulang sebelum digunakan kembali sebagai solusi dari masalah yang sedang dihadapi.

4) Retain; Menyimpan permasalahan baru ke dalam basis pengetahuan untuk digunakan kembali pada permasalahan berikutnya. Tahapan proses Case Based-Reasoning (CBR) dapat dilihat pada Gambar 2.

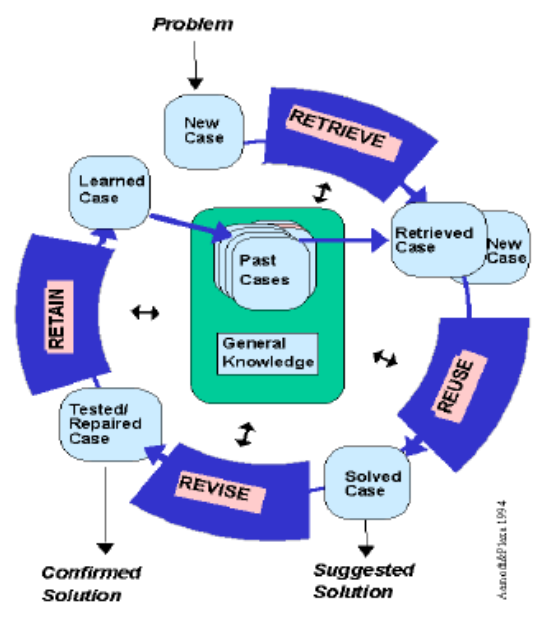

Gambar 2. Siklus Hidup Case Based-Reasoning (CBR) [11]

\section{METODOLOGI}

\section{A. Representasi Kasus}

Koleksi kasus didalam database kasus sangat menentukan hasil pencarian Case Based Reasoning (CBR). Mencari kemiripan pada kasus yang ada didalam database dengan permasalahan yang sedang dihadapi kemudian menggunakan solusi yang ada pada kasus yang terimpan didalam database untuk menyelesaikan permasalahan saat ini. Untuk itu koleksi data didalam database sangat menentukan tingkat penyelesaian permasalahan yang sedang dihadapi. Penyimpanan permasalahan dibuat berdasarkan: 1) Kejadian nyata yang menjadi sebuah problem, 2) dan Solusi yang merupakan penyelesaian terhadap permasalahan yang sedang dihadapi.

Agar mudah dalam menyimpan dan menggunakan kembali database yang ada, maka representasi kasus yang dibangun terdiri dari: 1) Remaja (berisi informasi klien), 2) Indikator masalah, 3) dan Indikator faktor kenakalan remaja; Untuk mempermudah proses pencarian permasalahan yang mirip yang akan digunakan adalah fitur. Untuk menyimpan data maka yang digunakan adalah indikator masalah, sedangkan indikator faktor kenakalan remaja merupakan output dari sistem yang akan menjelaskan tentang faktor yang mempengaruhi kenakalan dari klien (remaja).

Hal terpenting didalan Case-Based Reasoning adalah penyimpanan permasalahan. Dimana gambaran konseptual data akan tergambar didalam representasi kasus dan karakteristik kasus akan disimpan secara terindeks. Stuktur database kasus yang tersimpan akan sangat menentukan effesiensi pencarian dan metode penelusuran kembali.

\section{B. Penelusuran (Retrieval) dan Similaritas}

Data yang ada didalam database kasus akan digunakan kembali dengan melakukan penelusuran dan perbandingan terhadap fitur-fitur permasalahan pada kasus yang dihadapi dengan kasus didalam database. Setelah ditemukan hasil perbandingan tersebut akan dihitung nilai kemiripannya (similaritas) dengan menggunakan algoritma Nearst Neighboar. Dengan menggunakan algoritma kan dicari permasalahan yang mempunyai tingkat kemiripan yang tinggi antara permalahan yang dihadapi dengan permasalahan didalam database kasus.

Formula yang digunakan didalam algoritma Nearst Neighboar dalam menghitung nilai similaritas yang terdekat adalah [9]: 


$$
\operatorname{Sim}\left(\mathrm{T}, \mathrm{S}_{\mathrm{i}}\right)=\frac{\sum_{i=1}^{n} \int\left(T, S_{i}\right) w_{i}}{\sum_{i=1}^{n} w_{i}}
$$

Dengan ketentuan; T: permasalahan yang dihadapi, $S$ : permasalahan yang tersimpan didalama database kasus, $n$ : banyak atribut yang digunakan, $i$ : atribut individu antara $1 \mathrm{~s} / \mathrm{d} \mathrm{n}, f$ : fungsi similaritas atribut $\mathrm{i}$ antara kasus $\mathrm{T}$ dan kasus $\mathrm{S}, w$ : bobot yang diberikan pada atribut ke-i.

\section{Adaptasi Kasus}

Solusi yang ada pada permasalahan didalam database kasus dengan tingkat kemiripan tinggi yang ditemui, maka akan digunakan kembali sistem pada teknik, Case BasedReasoning (CBR). Dengan penambahan pengetahuan didalam database kasus, maka secara tidak langsung permasalahan didalam database kasus telah di update sehingga dapat digunakan kembali dimasa yang akan datang. Untuk mengupdate permasalahan didalam database kasus, pada teknik Case Based-Reasoning dapat dilakukan beberapa cara [10]: 1) Tidak Ada Adaptasi (Null Adaptation), 2) Penyesuaian Atau Pengaturan Parameter, 3) Reinstantiantioan, 4) Derivational Replay, 5) Perbaikam Model Terpandu.

Pada sistem ini menggunakan penyesuaian atau pengaturan parameter yaitu sistem akan melakukan penyesuaian terhadap indikator-indikator yang ada. Dan apabila kasus yang yang ditelusuri tidak ditemukan didalam database kasus maka sistem akan melakukan penyesuain terhadap kasus yang baru untuk dicarikan solusinya dan kasus itu akan disimpan untuk menambahkan koleksi pada database kasus yang telah ada.

\section{Analisis dan Perancangan Sistem \\ 1) Deskripsi Sistem}

Faktor kenakalan remaja merupakan objek yan akan digunakan untuk membangun sistem dengan menggunakan gejala yang ditemui pada remaja sebagai masukan, dan faktor yang mempengaruhi kenalan remaja sebagai target yang akan dicapai oleh sistem dengan basis Case Based-Reasoning (CBR).

\section{2) Akuisi pengetahuan}

Akuisi pengetahuan dalam menentukan faktor yang mempengaruhi kenakalan remaja merupakan proses untuk mengumpulkan data pengetahuan dari sumber pengetahuan dimana sumber pengetahuan yang akan dijadikan sebagai acuan dalam penelitian ini adalah: (a) Pakar yang dimaksud dalam penelitian ini adalah seorang psikolog. (b) Medical Record yang berhubungan dengan remaja yang menjadi klein. (c) Buku penunjang penelitian yang berhubungan dengan faktor-faktor yang mempengaruhi kenakalan remaja.

\section{3) Representasi Kasus}

Tahap awal yang dilakukan adalah dengan menetapkan idikator apa saja yang akan digunakan untuk membangun database kasus yang akan dibuat. Indikator kenakalan remaja yang akan digunakan didalam penelitian ini adalah: (a) Identitas, (b) Kontrol Diri, (c) Usia, (d) Jenis
Kelamin, (e) Harapan Terhadap Pendidikan dan Nilainilai di Sekolah, (f) Proses Keluarga, (g) Pengaruh Teman Sebaya, (h) Kelas Sosial Ekonomi, (i) dan Kualitas Lingkungan Sekitar Tempat Tinggal.

\section{4) Retrieval dan Similaritas}

Pada tahap ini akan dilakukan proses membandingkan (retrieval) seluruh indikator pada permasalahan yang ada dengan permasalahan didalam database kasus. Setelah itu akan di yang digunakan dalam penelitian ini adalah membandingkan setiap indikator kasus baru dengan indikator-indikator yang ada pada setiap kasus yang ada di dalam database kasus dengan menggunakan similaritas. Solusi pada permasalahan didalam database kasus akan kembali digunakan apabila nilai similaritas pada permasalahan didalam database kasus itu sama atau lebih besar nilainya dengan permasalahan yang sedang dihadapi.

Perhitungan nilai kedekatan (similaritas) dengan menggunakan algoritma Nearst Neighboar dengan batas nilai antara 0 sampai dengan 1 . Nilai kedekatan permasalahan yang sedang dihadapi dengan yang ada didalam database akan bernilai 0 apabila tidak mempunyai kemiripan sama sekali, dan akan bernilai 100\% apabila mempunyai kesamaan antara permasalahan yang dihadapi dengan yang ada didalam database kasus.

\section{5) Update Kasus}

Proses update data akan dilakukan terhadap permasalahan dengan nilai dibawah threshold atau tidak berhasil didiagnosa (nilai similaritas $=0$ ). Pada sistem ini indikator yang digunakan untuk menentukan akan diretain atau tidaknya permasalahan yang dihadapi adalah dengan menetapkan nilai threshold sebesar 0.85. Apabila nilai threshold tidak terpenuhi, maka permasalahan yang sedang dihadapi dengan sendirinya akan diperbaharui oleh database.

\section{HASIL DAN PEMBAHASAN}

\section{A. Tahap Pengisian Basis Kasus}

Tahap awal dari penggunaan sistem Case BasedReasoning (CBR) adalah pengisian database kasus. Data yang akan dijadikan database kasus adalah yang berhubungan dengan faktor yang dapat mempengaruhi kenakalan pada remaja.

\section{B. Tahap Diagnosa dan Update Kasus}

Database kasus akan diisi dengan menggunakan form pengisian yang memuat indikatir kasus dari fitur yang telah ditetapkan. Setelah itu dengan mencari tingkat kemiripan yang tinggi dari permasalahan yang dihadapi permasalahan didalam database kasus, maka akan digunakan kembali solusi yang ada pada permasalahan yag ada didalam database kasus dengan nilai nilai threshold sebesar 0.85. Proses update kasus akan dilakukan apabila kasus tidak didiagnosa. Proses update kasus dapat dilakukan jika:

1) Nilai kemiripan $=0$, hal ini menunjukkan bahwa permasalahan yang didiagnosa tidak ada didalam database 
kasus. Untuk itu kasus baru ini dapat digunakan untuk menambah pengetahuan pada permasalahan didalam database kasus.

2) Permasalahan baru dengan nilai threshold $<0.85$. yang menunjukkan rendahnya nilai kepercayaan.

\section{Pengujian Sistem}

Pengujian system dilakukan terhadap 250 kasus yag berasal dari medical record. Dimana 150 data digunakan sebagai database kasus, dan sisanya 100 data digunakan untuk menguji sistem. Ada 3 cara yang digunakan untuk menguji sistem yang dibuat ini, yaitu:

1) Pengujian tanpa threshold; Adapun 50 data digunakan untuk pengujian terhadap 150 permasalahan di dalam database kasus.

2) Pengujian dengan threshold; Data yang tersisa sebanyak 50, dilakukan untuk pengujian terhadap data didalam database kasus yang berjumlah 150 kasus.
3) Pengujian menggunakan 3 nilai threshold yang berbeda-beda yaitu: $0.50,0.85$ dan 0.95 .

Pengujian 1 dan 2 akan mengdiagnosa kasus baru dengan cara menghitung similaritas antara kasus baru (100 kasus) dengan kasus yang tersimpan di database kasus (150 kasus).

\section{Pengujian tanpa Threshold}

Penggunaan 50 permasalahan baru yang berbeda terhadap permasalahan didalam database kasus dengan menggunakan algoritma Nearst Neighboar yang dilakukan sebanyak 5 kali. Pengujian 1 yang dilakukan terhadap 20 kasus baru dapat dilihat pada Tabel 1. Pada Tabel 2 diperlihatkan nilai similaritas dan faktor penyebab kenakalan berdasarkan perhitungan dengan menggunakan algoritma Nearst Neighboar pada 50 kasus permasalahan baru yang di-input-kan.

Tabel 1. Hasil Diagnosa Algoritma Nearst Neighboar terhadap Pakar untuk 50 Kasus Baru yang Diuji

\begin{tabular}{llll}
\hline Kasus Baru & Similaritas & Faktor yang Mempengaruhi & Pakar \\
\hline 1 & 0.9 & Kontrol diri & Kontrol diri \\
2 & 0.86 & Identitas & Identitas \\
3 & 0.95 & Proses keluarga & Proses keluarga \\
4 & 0.8 & Usia & Usia \\
5 & 0.85 & Jenis Kelamin & Jenis Kelamin \\
6 & 0.88 & Kelas sosial ekonomi & Kelas sosial ekonomi \\
7 & 0.9 & Proses keluarga & Proses keluarga \\
8 & 0.9 & Harapan terhadap pendidikan dan nilai-nilai disekolah & Harapan terhadap pendidikan dan nilai-nilai disekolah \\
9 & 0.9 & Pengaruh teman sebaya & Pengaruh teman sebaya \\
10 & 0.85 & Kelas sosial ekonomi & Kelas sosial ekonomi \\
11 & 0.92 & Proses keluarga & Proses keluarga \\
12 & 0.89 & Pengaruh teman sebaya & Pengaruh teman sebaya \\
13 & 0.9 & Kualitas lingkungan sekitar tempat tinggal & Kualitas lingkungan sekitar tempat tinggal \\
14 & 0.89 & Kontrol diri & Kontrol diri \\
15 & 0.92 & Kualitas lingkungan sekitar tempat tinggal & Kualitas lingkungan sekitar tempat tinggal \\
16 & 0.65 & Jenis Kelamin & Jenis Kelamin \\
17 & 0.88 & Identitas & Identitas \\
18 & 0.89 & Kelas sosial ekonomi & Kelas sosial ekonomi \\
19 & 0.89 & Harapan terhadap pendidikan dan nilai-nilai disekolah & Harapan terhadap pendidikan dan nilai-nilai disekolah \\
20 & 0.93 & Proses keluarga & Proses keluarga \\
\hline
\end{tabular}

Dari hasil pengujian 100 kasus baru diperoleh ratarata prosentase keakurasian diagnosa 100 kasus baru yang diuji menggunakan algoritma Nearst Neighboar terhadap diagnosa pakar sebesar 89\%. Prosentase keakurasian dapat dilihat pada Gambar 2.

Pengujian juga dilakukan dengan menghitung ratarata berdasarkan banyaknya kasus berdasarkan faktor yang dapat mempengaruhi kenakalan remaja. Pengujian dilakukan terhadap kasus baru yang ke 50 diperoleh nilai rata-rata similaritas dapat dilihat pada Tabel 2.

Dari Table 2 dijelaskan bahwa faktor keluarga mempunyai nilai similaritas tertinggi dari hasil uji coba 50 permasalahan kenakalan remaja yang baru terhadap 150 permasalahan yang tersimpan didalam database.

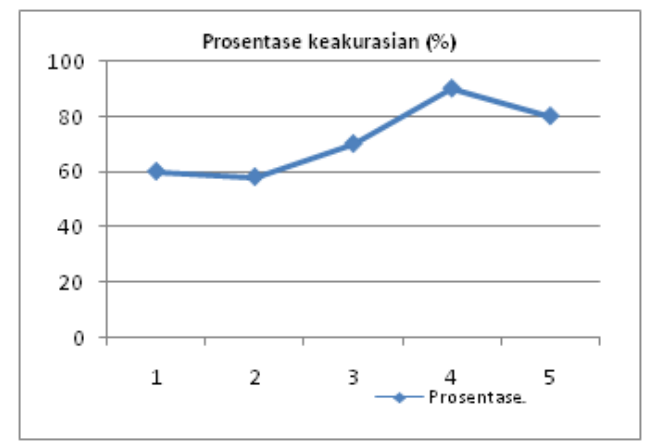

Gambar 2. Prosentase 5 Kali Pengujian Terhadap 100 Kasus Baru dengan Algoritma Nearst Neighboar 
Tabel 2. Nilai Rata-rata Berdasarkan Faktor yang Mempengaruhi

\begin{tabular}{ll}
\hline Faktor yang Mempengaruhi & Rata-rata Similaritas \\
\hline Identitas & 0.87 \\
Kontrol diri & 0.895 \\
Usia & 0.8 \\
Jenis Kelamin & 0.425 \\
Harapan terhadap pendidikan dan nilai-nilai disekolah & 0.895 \\
Proses keluarga & 0.925 \\
Pengaruh teman sebaya & 0.895 \\
Kelas sosial ekonomi & 0.873 \\
Kualitas lingkungan sekitar tempat tinggal & 0.91 \\
\hline
\end{tabular}

Tabel 3. Prosentase Banyaknya Kasus Berdasarkan Threshold

\begin{tabular}{llll}
\hline \multirow{2}{*}{ No. } & Kasus Baru & \multicolumn{3}{l}{ Banyaknya Kasus Berdasarkan Threshold } \\
\cline { 2 - 4 } & 0,5 & 0,75 & 0,80 \\
\hline 1 & 20 & 7 & 1 \\
2 & 20 & 2 & 0 \\
3 & 20 & 5 & 0 \\
4 & 20 & 3 & 0 \\
5 & 20 & 5 & 0 \\
6 & 20 & 5 & 0 \\
7 & 20 & 10 & 0 \\
8 & 20 & 4 & 0 \\
9 & 20 & 12 & 3 \\
10 & 20 & 4 & 0 \\
11 & 0,5 & 0,75 & 0,80 \\
12 & 20 & 6 & 0 \\
13 & 20 & 4 & 0 \\
14 & 20 & 4 & 0 \\
15 & 20 & 2 & 0 \\
16 & 20 & 4 & 0 \\
17 & 20 & 9 & 0 \\
18 & 0,5 & 0,75 & 0,80 \\
19 & 20 & 3 & 0 \\
20 & 20 & 4 & 0 \\
\hline
\end{tabular}

Seperti yang tampak pada table 3 dijelaskan bahwa hasil pengujian yang dilakukan kasus 1 terhadap 150 kasus yang ada dalam database kasus diperoleh nilai thereshold sebagai berikut:

1) Banyaknya kasus yang berada di threshold 0.50 sebanyak 150 kasus (100\%). Hal ini berarti semua nilai similaritas kasus 1 terhadap 150 kasus yang ada didatabase kasus berada di atas nilai threshold 0.5 .

2) Threshold 0.75 sebanyak 19 kasus (12.67\% dari 150 kasus)

3) Threshold 0.80 sebanyak 1 kasus $(0.67 \%$ dari 150 kasus)

Threshold 0.85 diperoleh dari pengujian permasalahan dengan hasil sebanyak 46 kasus dari 100 kasus baru yang diuji. Treshold (0.50, 0.85 dan 0.95) terhadap 150 kasus yang diuji dapat dilihat pada tabel 3 diatas.

\section{KESIMPULAN}

Kesimpulan yang diambil dari hasil pengamatan dan uji coba adalah: (a) Faktor yang mempengauhi digunakan sebagai target sistem, dan indikator masalah digunakan sebagai masukan sistem. (b) Ditetapkan batasan nilai kemiripan yaitu berkisar dari 0 sampai dengan 1 . Dikatakan tidak mempunyai kemiripan apabila kasus baru mempunyai nilai similaritas $=0$, dan similaritasnya diatas
0.85 maka permasalahan didalam database kasus mempunyai kesamaan dengan permasalahan yang sedang dihadapi. (c) Dari hasil perhitungan similaritas dengan menggunakan algoritma Nearst Neighboar untuk melakukan perbandingan terhadap setiap indikator antara permasalahan didalam database dengan permasalahan yang dihadapi untuk diperoleh angka kemiripan yang tinggi. (d) Nilai akurasi sebesar $89 \%$ diperoleh setelah dilakukan ujicoba terhadap 100 data permasalahan baru terhadap 150 data permasalahan didalam database kasus dengan menggunakan algoritma Nearst Neighboar. (e) Ada dua kondisi update kasus, yaitu: 1) Tidak adanya kemiripan dengan permasalahan didalam data base kasus (similaritas $=0$ ). 2) Ditemukannya permasalahan dengan derajat kepercayaan yang rendah karena nilai kemiripan $<0.85$.

\section{DAFTAR PUSTAKA}

[1] Zakiah, Daradjat; (1989). Pendekatan Psikologis dan Fungsi keluarga dalam Menanggulangi Kenakalan Remaja. Semarang.

[2] Djiwandono \& Mulyani, (2002), Psikologi pendidikan. Grasindo.

[3] Haditono. S.R, (1998), Penelitian sebab-sebab kenakalan remaja. Jakarta. Jurnal Psikologi.

[4] Hurlock, E.B, (1998). Adolescence development. Tokyo. Mc Graw Hill. 
[5] Willis. S. (1994). Problema remaja dan pemecabannya. Bandung. Angkasa.

[6] Kartono. K. (1991), Bimbingan bagi anak dan remaja yang bermasalah. Jakarta. Raja Wali Pers.

[7] Humaedi. Sahadi, et.al, (2017). Kenakalan Remaja dan Penangannya, Jurnal Penelitian \& PPM ISSN: 2442448. Vol 4. No: 2 Hal: 129 - 389.

[8] Watson, I. (1997). Applying Case-Based Reasoning, Technique for Enterprise Systems, Morgan Kaufmann Publishers.
[9] Kusrini, (2008), Aplikasi Sistem Pakar. Andi Offset, Yogyakarta.

[10] Pal. K. Sankar \& Simon. (2004). Foundations Of Soft Case-Based Reasoning.Wiley-Interscience.

[11] K.D. Althoff, (2001). Case-Based Reasoning. Handbook of Software Engineering \& Knowledge Engineering (ed. S.K. Chang) Vol 1. World Scientific. Singapore. 